\title{
BED-STATES* IN THE DOMINIONS
}

\author{
BY \\ RICHARD PADLEY \\ From the Department of Medical Statistics, University of Birmingham
}

International comparison of administrative statistics is notoriously a march across quicksands. At no step is it certain that conditions applicable to the last foothold still obtain, and progress is dependent on continual circumspection. Attempts to compare the provision of beds in public hospitals in the constituent Dominions of the Empire prove no exception to this general rule of confusion. The number of beds required for a population will depend first of all on general social and medical practice as deciding which conditions are treated institutionally and which in the home. Within this framework the determining factors are the level of incidence of the conditions requiring hospital treatment and the length of time which such treatment lasts. Both these variables have different typical levels for the two sexes and at different ages. Incidence may vary with the season of the year, and length of stay in hospital with a variety of administrative arrangements. As yet we are far from any exact statistical treatment of the costing problem involved. Nevertheless, the problem is of current urgency, and examination of published information may prove revealing.

Only a minority of the countries of the Empire is available for such study. The new Dominions of Asia are as yet too young in self-government, and too unlike Western industrial communities, to have produced a hospital system comparable with the older imperial countries; while the Government of the Union of South Africa, in pursuit of a local ideology, concerns itself disproportionately with a minority of the population selected by the curiously inappropiate factor of - skin pigment. What follows, therefore, is restricted to the three relatively similar communities of Australia, Canada, and New Zealand.

Equipped Beds in Australia, New Zealand, ANd CANADA

There is, of course, no coherence of plan imposed on the figures published by these three Dominions, and interpretation of apparently comparable data

\footnotetext{
"The term " " bed-state " will be familiar to some of our readers as the term employed in Army hygiene for hospital accommodation accountancy. It has the advantage of brevity.
}

must be subject to local variations of organization and procedure. With due regard to such difficulties Table I summarizes available information on total equipped beds. Figures given refer to hospitals defined as follows:

(i) Australia. "All institutions affording hospital relief, whether general or special, with the exception of hospitals for the insane and private hospitals conducted commercially."

(ii) New Zealand. " All public hospitals, including departmental institutions." It should be noted that the New Zealand official report gives a total of 12,497 equipped beds for 1943-4 in its summary table, while the sum of a more detailed breakdown of ostensibly the same figure in another table comes to 13,587 beds. It may be that the former figure, which is quoted in Table $I$, represents a mid-year average while the latter is a census count at a particular date, but this is nowhere explicitly stated.

(iii) Canada. Figures for Canada are far more detailed and ambitious and hence more difficult of interpretation, since sources of inaccuracy are honestly displayed and not concealed behind deceptive totals. Figures here quoted relate to 587 out of 600 public hospitals for acute diseases known to be operating. These represent all the hospitals which made reports to the central authority. To them are added tuberculosis sanatoria and special units in public and general hospitals established for the care of tuberculosis patients. Private hospitals are excluded.

It will be noted from the Table that, with the exception of the Yukon where obviously unusual conditions obtain, these is a remarkable similarity in the scales of total bed provision. The range is from 3.4 per 1,000 population in Victoria to 7.7 per 1,000 in Tasmania. These figures are nearly all, it will be observed, below the scales, 
TABLE I

Total Bed-State Dominion Public Hospitals

\begin{tabular}{|c|c|c|c|c|c|c|}
\hline & $\begin{array}{c}1 . \\
\text { Population } \\
\text { in 1,000's }\end{array}$ & $\begin{array}{c}2 . \\
\text { Number of } \\
\text { equipped beds }\end{array}$ & $\begin{array}{c}3 . \\
\text { Number of } \\
\text { beds per } 1,000 \\
\text { population }\end{array}$ & $\begin{array}{c}4 . \\
\text { Average daily } \\
\text { number in } \\
\text { hospital }\end{array}$ & \multicolumn{2}{|c|}{$\begin{array}{l}5 . \\
\text { io of Col. } 2 \text { to } \\
\text { Col. } 4\end{array}$} \\
\hline 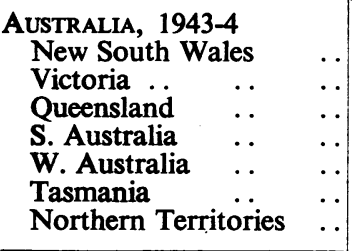 & $\begin{array}{r}2,870 \\
1,997 \\
1,065 \\
622 \\
485 \\
245 \\
5\end{array}$ & $\begin{array}{r}16,820 \\
7,468 \\
6,965 \\
2,956 \\
3,447 \\
1,895 \\
-\end{array}$ & $\begin{array}{c}5 \cdot 86 \\
3 \cdot 74 \\
6 \cdot 54 \\
4 \cdot 75 \\
7 \cdot 10 \\
7 \cdot 72 \\
-\end{array}$ & $\begin{array}{r}12,218 \\
5,512 \\
4,814 \\
2,018 \\
1,909 \\
1,102 \\
-\end{array}$ & \multicolumn{2}{|c|}{$\begin{array}{c}1.38 \\
1.35 \\
1.45 \\
1.46 \\
1.81 \\
1.72 \\
-\end{array}$} \\
\hline Total $\quad \ldots \quad \ldots$ & 7,290 & 39,551 & $5 \cdot 43$ & 27,573 & \multicolumn{2}{|c|}{$1 \cdot 43$} \\
\hline New Zealand, 1943-4 $\ldots$ & 1,636 & 12,497 & $7 \cdot 64$ & 10,412 & \multicolumn{2}{|c|}{$1 \cdot 20$} \\
\hline 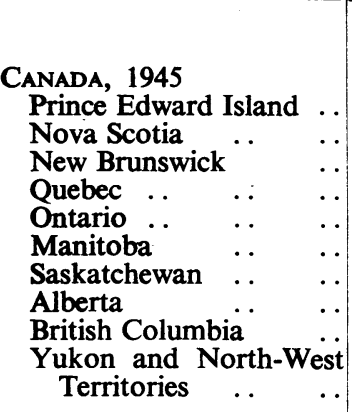 & $\begin{array}{r}92 \\
621 \\
468 \\
3,561 \\
4,004 \\
736 \\
845 \\
826 \\
949 \\
\\
17\end{array}$ & $\begin{array}{r}398 \\
3,251 \\
2,166 \\
17,156 \\
19,771 \\
4,386 \\
4,790 \\
5,539 \\
6,085 \\
233\end{array}$ & $\begin{array}{l}4 \cdot 32 \\
5 \cdot 24 \\
4 \cdot 63 \\
4 \cdot 82 \\
4 \cdot 94 \\
5 \cdot 96 \\
5 \cdot 67 \\
6 \cdot 71 \\
6 \cdot 41 \\
13 \cdot 71\end{array}$ & $\begin{array}{l}\overline{-} \\
\overline{-} \\
= \\
\bar{z} \\
=\end{array}$ & \begin{tabular}{|c|}
$\begin{array}{c}\text { T.B. Sana- } \\
\text { toria }\end{array}$ \\
$1 \cdot 70$ \\
$1 \cdot 12$ \\
1.05 \\
1.09 \\
$1 \cdot 18$ \\
$1 \cdot 19$ \\
1.05 \\
1.13 \\
1.12 \\
-
\end{tabular} & $\begin{array}{c}\text { Others } \\
1 \cdot 27 \\
1 \cdot 30 \\
1 \cdot 34 \\
1 \cdot 28 \\
1 \cdot 25 \\
1 \cdot 34 \\
1 \cdot 41 \\
1 \cdot 48 \\
1 \cdot 35 \\
2 \cdot 06\end{array}$ \\
\hline Total & 12,119 & 63,758 & $5 \cdot 26$ & - & $1 \cdot 13$ & $1 \cdot 32$ \\
\hline
\end{tabular}

ranging from $7 \cdot 1$ to 9.9 per 1,000 , suggested for England and Wales by the regional Hospital Surveys of 1945; and they are also probably below the comparable figure of 6.0 per 1,000 population exclusive of accommodation for the chronic sick suggested by Emerson (1943) as a result of the New York hospital survey. Subsequent columns give some idea of the necessary insurance involved in planning hospital accommodation. Column 4 of the Table shows for Australia and New Zealand the average daily number of patients accommodated, and this is converted into comparable terms by giving in column 5 the ratio of equipped beds to average daily number in use. The information of column 4 is not available for Canada as a whole, since complete returns were made by a proportion only of the hospitals reporting. The ratios shown in column 5 are based on those hospitals that did provide information, and are probably biased for comparison with the other two Dominions by the exclusion disproportionately of the smaller institutions. The variation of the insurance ratios is quite considerable, but regression analysis shows

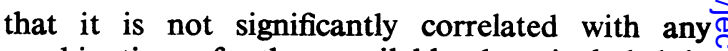
combination of other available data included in? the present Tables. The figures for Canada, however, which separate tuberculosis from other diseases, give a very strong suggestion that average duration of stay in hospital is at least one of the determining factors in determining the optimum size for this ratio.

\section{Staffing of Hospitals}

Availability of staff, and in particular nursing staff, is a major contemporary factor limiting the scale of hospital provision. Table II gives figures $\omega$ published by official sources for the staffing of hospitals. Variations of practice relating to the work of honorary and consulting medical staff make crude figures such as are available here? unreliable as giving anything but the broadest outline picture. Figures for total nursing staff, $\underset{\mathbb{D}}{\stackrel{D}{\mathbb{N}}}$ including probationers and student nurses, are, on $\frac{\Omega}{\Phi}$ the other hand, remarkably constant. Over the $\varrho$ three dominions the scale of equipped beds per nurse ranges from 1.9 in Victoria and New Zealand $\delta$ 
TABLE II

Staff Situation Dominion Public Hospitals

I. Australia: All Public Hospitals other than Hospitals for tíe Insane

\begin{tabular}{|c|c|c|c|c|c|c|c|c|c|c|}
\hline & & & & \multirow{2}{*}{\multicolumn{3}{|c|}{ Medical Staff }} & \multirow{3}{*}{ Total } & \multirow{3}{*}{$\begin{array}{c}\text { Total } \\
\text { nursing } \\
\text { staff }\end{array}$} & \multicolumn{2}{|c|}{ Equipped } \\
\hline & & & & & & & & & Beds per & Beds per \\
\hline & & & & & Honorary & Salaried & & & doctor & nurse \\
\hline $\begin{array}{l}\text { New South Wales } \\
\text { Victoria } \\
\text { Queensland } \\
\text { S. Australia } \\
\text { W. Australia } \\
\text { Tasmania }\end{array}$ & $\begin{array}{l}\cdots \\
\cdots \\
\cdots \\
\cdots \\
\cdots\end{array}$ & $\begin{array}{l}\cdots \\
\cdots \\
\cdots \\
\cdots \\
\cdots\end{array}$ & $\begin{array}{l}\cdots \\
\cdots \\
\cdots \\
\cdots \\
\cdots\end{array}$ & $\because$ & $\begin{array}{r}1,639 \\
803 \\
165 \\
253 \\
72 \\
96\end{array}$ & $\begin{array}{r}336 \\
268 \\
172 \\
117 \\
35 \\
50\end{array}$ & $\begin{array}{r}1,975 \\
1,071 \\
337 \\
370 \\
107 \\
146\end{array}$ & $\begin{array}{r}6,310 \\
4,004 \\
3,190 \\
1,281 \\
1,096 \\
541\end{array}$ & $\begin{array}{r}9 \cdot 0 \\
7 \cdot 0 \\
20 \cdot 7 \\
8 \cdot 0 \\
32 \cdot 2 \\
13 \cdot 0\end{array}$ & $\begin{array}{l}2 \cdot 7 \\
1 \cdot 9 \\
2 \cdot 2 \\
2 \cdot 3 \\
3 \cdot 1 \\
3 \cdot 5\end{array}$ \\
\hline Total & $\ldots$ & . & $\ldots$ & & 3,028 & 978 & 4,006 & 16,422 & $9 \cdot 9$ & $2 \cdot 4$ \\
\hline
\end{tabular}

II. New Zealand: All Public Hospitals

\begin{tabular}{l|c|c|c|c|c|c|c}
\hline & & & \multicolumn{2}{|c|}{$\begin{array}{c}\text { Total } \\
\text { Visiting }\end{array}$} & Stipendiary & Total & \multicolumn{2}{|c|}{$\begin{array}{c}\text { Equipped } \\
\text { staff }\end{array}$} & $\begin{array}{c}\text { Beds per } \\
\text { doctor }\end{array}$ & $\begin{array}{c}\text { Beds per } \\
\text { nurse }\end{array}$ \\
\hline & 381 & 569 & 950 & 6,458 & $13 \cdot 6$ & $1 \cdot 9$ \\
\hline
\end{tabular}

III. Canada: Hospitals for Acute Diseases excluding T.B. Sanatoria and Hospitals for the Insane

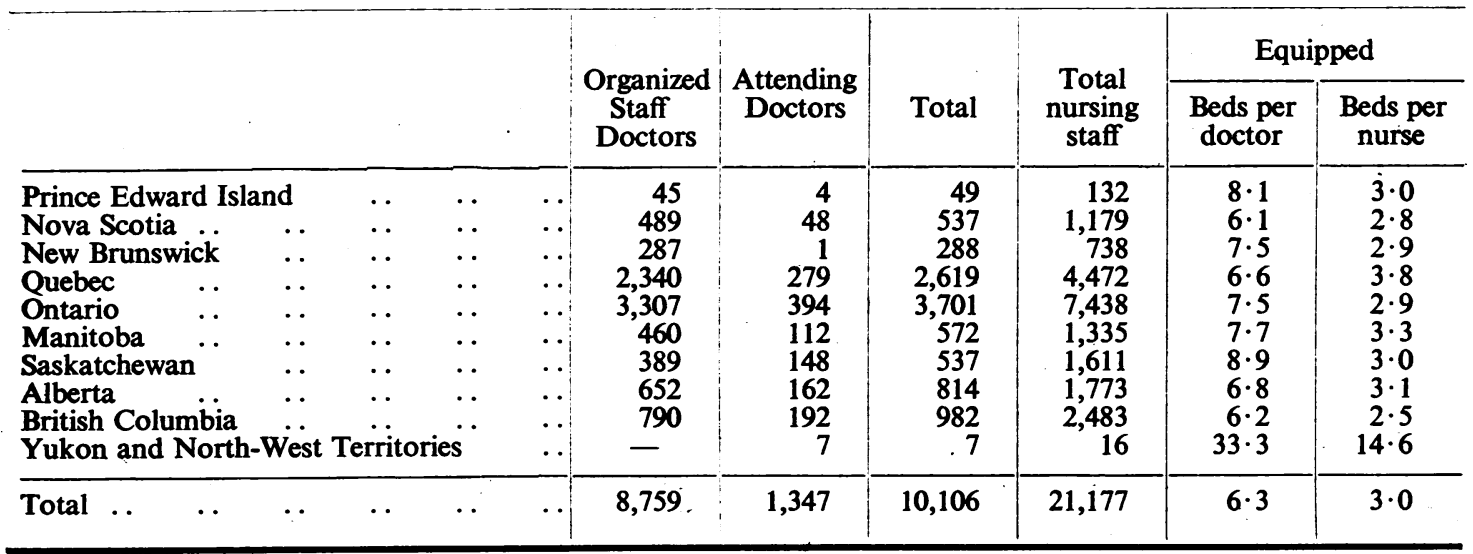


to $3 \cdot 8$ in Quebec. Unfortunately more detailed figures giving hours of work and subdividing hospitals into categories whose patients require more or less nursing attention are not available.

\section{EXPENDITURE}

Total expenditure, which is not readily reducible to a common measure in view of price disparity between the countries, is shown in local currency in Table III.

TABLE III

Total Expenditure on Public Hospitals

\begin{tabular}{|c|c|c|}
\hline & $\begin{array}{c}\text { Per } \\
\text { equipped } \\
\text { bed }\end{array}$ & $\begin{array}{l}\text { Per } \\
\text { patient } \\
\text { day }\end{array}$ \\
\hline $\begin{array}{l}\text { Australia } 1943-4(\text { (£s A.) } \\
\text { New Zealand 1943-4 (£s N.Z.) } \\
\text { Canada } 1945(\$) \text { : }\end{array}$ & $\begin{array}{l}219 \cdot 2 \\
266 \cdot 1\end{array}$ & $\begin{array}{l}0 \cdot 86 \\
0 \cdot 87\end{array}$ \\
\hline $\begin{array}{l}\text { (i) Hospitals for acute diseases } \\
\text { (ii) T.B. sanatoria and institutions }\end{array}$ & \begin{tabular}{|l|l|} 
& $1,161 \cdot 6$ \\
& $842 \cdot 9$
\end{tabular} & $\begin{array}{l}4 \cdot 45 \\
3 \cdot 2\end{array}$ \\
\hline
\end{tabular}

\section{Allocation of Beds for Various Conditions}

The foregoing Tables virtually exhaust available data of administrative interest that are capable of comparison between the three Dominions. In so far as the organization of medical care necessarily varies with demographic, social, and economic conditions, it is inevitable that statistics recording administrative effort in different countries should be differently based. To some extent the pursuit of comparability is necessarily the pursuit of a lowest common denominator. Figures are available for New Zealland and Canada for the subdivision of the total bed-state into allocations for various special conditions. These are shown in Table IV. It will readily be seen that such subdivisions are far more liable to vary than total bed-states; this is due not only to differences of local practice, but also to differences of local nomenclature and accounting procedure.

In particular, lying-in accommodation may be expected to vary according as local practice or sentiment favours institutional or domiciliary midwifery. In this connexion some interesting figures are available for Canada (Table V).

Two points are worthy of comment. The very high proportion of stillbirths that take place in hospital in most provinces speaks highly for the prognostic efficiency of antenatal services. Further analysis of this point would, however, depend on the breakdown of stillbirths by recorded cause and stage of pregnancy at which the mother was admitted to hospital. Secondly, there is clearly an association, in Canada at least, between high fertility and domiciliary labour.

It would be unwise, however, to assume that the association is necessarily due to the lower proportion of primagravidae in high-fertility areas. Charles (1945) has shown that fertility in Canada is associated with a number of social conditions, and these are also therefore associated with the choice of $\vec{\circ}$ lying-in arrangements. In particular low educational standards and rural domicile, which are part of the high-fertility pattern, may well be expected to accompany habits of giving birth to children in $?$ the home rather than in hospital.

Mental Institutions in Australia and Canada

So far all figures presented have excluded mental institutions. Bed-state and staff figures are available $\rightarrow$ for Australia and Canada, and these are shown in Table VI. Staff figures as presented are necessarily difficult of any but the crudest interpretation owing to lack of precise indication of who is included under the two main headings. It is certain that the Canadian figure for nurses and attendants excludes matrons, dieticians, occupational therapists, teachers and social workers, and this may in some small part account for the discrepancy between the two countries.

The bed-state situation for such institutions is in any case unique as a result of the lengthy stay of most patients. In consequence the equilibrium number of beds required to maintain a balance between admissions and discharges is necessarily very high relative to the admission rate. Moreover improved diagnosis, and a changing public attitude that is gradually removing the stigma formerly attached to admission to mental hospitals are still resulting in an increasing rate of admission in most 옥 countries.

\section{Duration of Stay in Hospital}

Figures for duration of stay in hospital are $N$ necessary to any attempt at costing bed-state N requirements. Existing public statistics, however, $\omega$ including those produced by the Dominion Bureau of Statistics for Canada, content themselves with $\stackrel{\odot}{\leftarrow}$ giving the mean duration of stay of persons dis- $\stackrel{\mathcal{P}}{?}$ charged from or dying in hospital during a given 0 period of time.

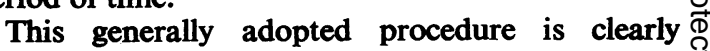
unsatisfactory even for giving the mean duration $\mathbb{D}$ of stay, which is of little use without some knowledge of the range. It is impossible to link figures for discharges during a given period with those for 
TABLE IV

Distribution of Hospital Accommodation

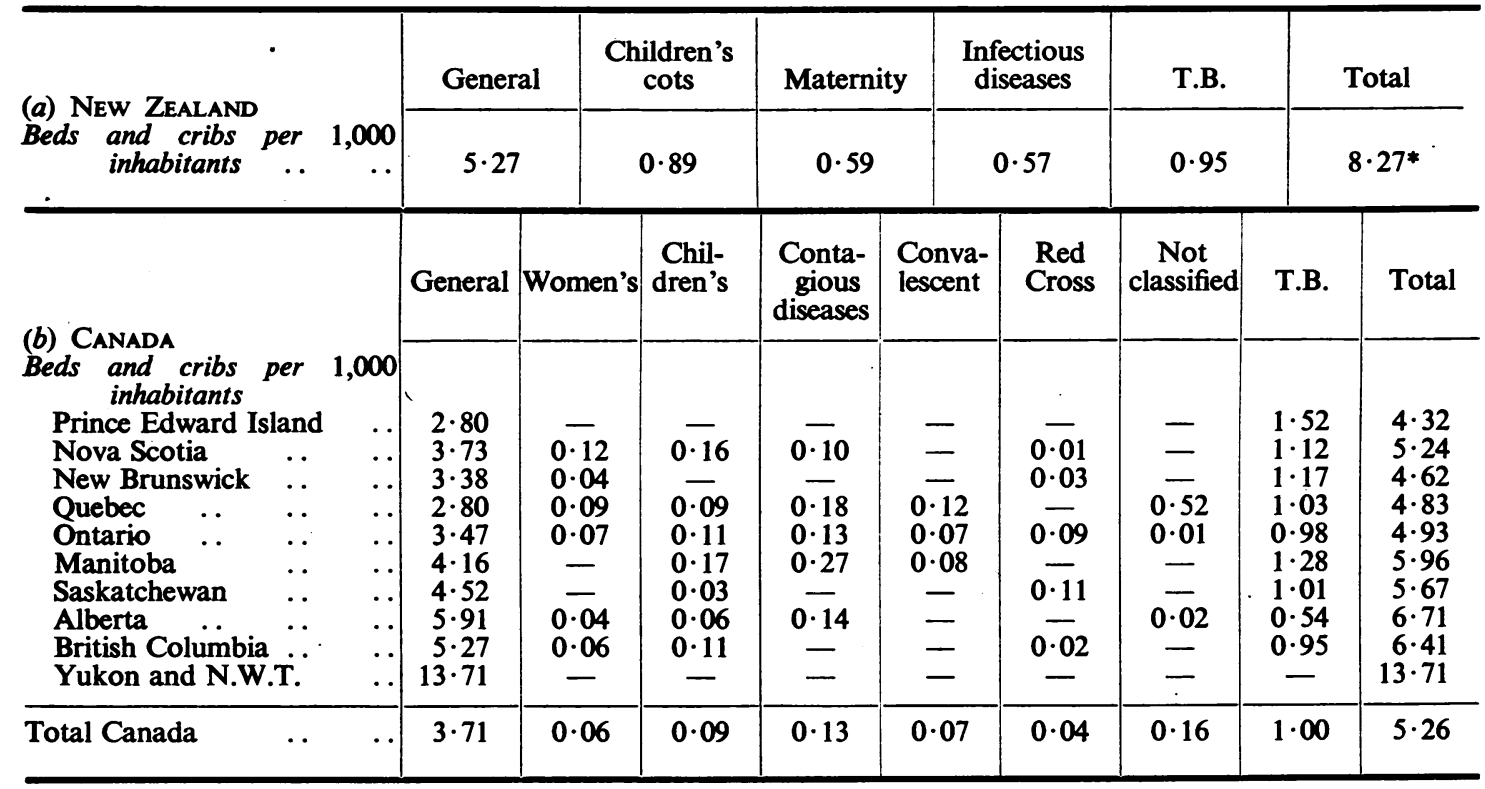

- This differs from the figure in Table I. See p. 46 above.

TABLE V

Use of Maternity Hospitals: Canada, 1945

\begin{tabular}{|c|c|c|c|c|c|c|}
\hline & \multicolumn{3}{|c|}{$\begin{array}{l}\text { Percentage of births taking place in } \\
\text { hospitals, } 1945^{*}\end{array}$} & \multicolumn{2}{|c|}{$\begin{array}{c}\text { Crude birth rate per } 1,000 \\
\text { population }\end{array}$} & \multirow{2}{*}{$\begin{array}{c}\begin{array}{c}\text { Gross } \\
\text { reproduction } \\
\text { rate }\end{array} \\
1944\end{array}$} \\
\hline & Live births & Stillbirths & All births & $\begin{array}{l}\text { Average } \\
1936-40\end{array}$ & 1944 & \\
\hline 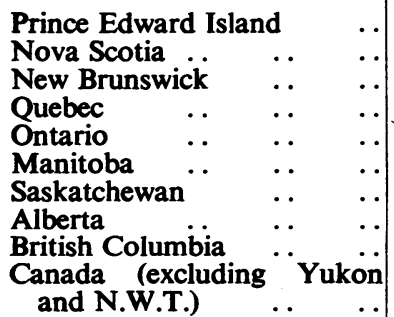 & $\begin{array}{l}37 \cdot 8 \\
75 \cdot 3 \\
48 \cdot 3 \\
34 \cdot 4 \\
79 \cdot 1 \\
81 \cdot 2 \\
82 \cdot 1 \\
89 \cdot 1 \\
93 \cdot 5 \\
62 \cdot 9\end{array}$ & $\begin{array}{l}50 \cdot 0 \\
90 \cdot 1 \\
71 \cdot 6 \\
39 \cdot 9 \\
88 \cdot 2 \\
93 \cdot 5 \\
91 \cdot 2 \\
99 \cdot 0 \\
92 \cdot 0 \\
67 \cdot 2\end{array}$ & $\begin{array}{l}37 \cdot 8 \\
75 \cdot 5 \\
48 \cdot 8 \\
34 \cdot 5 \\
79 \cdot 3 \\
81 \cdot 4 \\
82 \cdot 4 \\
89 \cdot 3 \\
93 \cdot 5 \\
63 \cdot 0\end{array}$ & $\begin{array}{l}21 \cdot 9 \\
21 \cdot 7 \\
25 \cdot 1 \\
24 \cdot 6 \\
17 \cdot 5 \\
18 \cdot 8 \\
20 \cdot 4 \\
20 \cdot 8 \\
15 \cdot 6 \\
20 \cdot 5\end{array}$ & $\begin{array}{l}25 \cdot 1 \\
25 \cdot 5 \\
29 \cdot 1 \\
29 \cdot 2 \\
19 \cdot 7 \\
21 \cdot 9 \\
21 \cdot 4 \\
23 \cdot 7 \\
20 \cdot 4 \\
23 \cdot 8\end{array}$ & $\begin{array}{l}1.914 \\
1 \cdot 549 \\
1.954 \\
1 \cdot 773 \\
1 \cdot 192 \\
1 \cdot 303 \\
1 \cdot 462 \\
1 \cdot 411 \\
1 \cdot 186 \\
1 \cdot 455\end{array}$ \\
\hline
\end{tabular}

- Includes both private and public hospitals. 
admissions during the same period, and in certain circumstances this may produce a very misleading picture. During a period when the number of occupied beds is increasing, discharge figures will include a concentration of cases of shorter duration, since the long-term occupants of new beds will still be in hospital at the accounting date. Conversely, when-as happens for example in an army at the end of war-hospital beds are being closed down, a time will come when all the short-term sick have left the contracting wards and only cases of long duration remain to be included at the next return.

Ideally the true picture can be given only by following up a group of admissions until every case has reached its ultimate disposal. Where statistics are prepared by punch-card machinery on a basis of one card to each case this can be done, and in certain circumstances-where, for example, duration of treatment is an admissible yardstick of therapeutic efficiency-it is desirable that it should be done. But it is cumbersome administratively and involves necessary delay. For administrative purposes some middle way is desirable that avoids the error of counting only discharges and the delay of waiting till every admission is discharged or dead.

Such a short cut may be devised by a simple adaptation of the life table, which solves an essentially similar problem. The solution obtained has the merit of giving the full distribution of duration of stay, for which the mean may be an inadequate parameter. It is hoped to make this the subject of a future communication.

For Canada we are, in fact, presented with two sets of figures for the average duration of stay. The first is derived from the total days spent in hospital by all persons discharged or dying during

TABLE VI

Bed-State and Staff Situation in Mental Instrtutions

\begin{tabular}{|c|c|c|c|c|c|c|c|c|}
\hline & \multicolumn{2}{|c|}{$\begin{array}{c}\text { Number of beds and } \\
\text { cots }\end{array}$} & \multicolumn{2}{|c|}{$\begin{array}{l}\text { Number of patients on } \\
\text { books at end of year }\end{array}$} & \multicolumn{2}{|c|}{ Medical staff } & \multicolumn{2}{|c|}{$\begin{array}{c}\text { Nursing staff and } \\
\text { attendants }\end{array}$} \\
\hline & $\begin{array}{l}\text { Crude } \\
\text { total }\end{array}$ & $\begin{array}{c}\text { Per 1,000 } \\
\text { inhabitants }\end{array}$ & $\begin{array}{l}\text { Crude } \\
\text { total }\end{array}$ & $\begin{array}{c}\text { Per 1,000 } \\
\text { inhabitants }\end{array}$ & $\begin{array}{l}\text { Crude } \\
\text { total }\end{array}$ & $\begin{array}{c}\text { Per } 1,000 \\
\text { equipped } \\
\text { beds }\end{array}$ & $\begin{array}{l}\text { Crude } \\
\text { total }\end{array}$ & $\begin{array}{c}\text { Per } 1,000 \\
\text { equipped } \\
\text { beds }\end{array}$ \\
\hline \multicolumn{9}{|l|}{ 1. Australia $^{*}$} \\
\hline $\begin{array}{l}\text { New South Wales } \\
\text { Victoria } . . \\
\text { Queensland } \\
\text { S. Australia } \\
\text { W. Australia } \\
\text { Tasmania .. }\end{array}$ & $\begin{array}{r}11,411 \\
6,671 \\
3,876 \\
2,092 \\
1,446 \\
750\end{array}$ & $\begin{array}{l}4 \cdot 0 \\
3 \cdot 9 \\
3 \cdot 8 \\
3 \cdot 4 \\
3 \cdot 0 \\
3 \cdot 0\end{array}$ & $\begin{array}{r}11,789 \\
6,319 \\
3,666 \\
1,883 \\
1,426 \\
646\end{array}$ & $\begin{array}{l}4 \cdot 1 \\
3 \cdot 7 \\
3 \cdot 6 \\
3 \cdot 1 \\
3 \cdot 0 \\
2 \cdot 6\end{array}$ & $\begin{array}{r}39 \\
32 \\
10 \\
8 \\
5 \\
3\end{array}$ & $\begin{array}{l}3 \cdot 4 \\
4 \cdot 8 \\
2 \cdot 6 \\
3 \cdot 8 \\
3 \cdot 5 \\
4 \cdot 0\end{array}$ & $\begin{array}{r}1,654 \\
991 \\
571 \\
340 \\
243 \\
159\end{array}$ & $\begin{array}{l}144 \cdot 9 \\
148 \cdot 6 \\
147 \cdot 3 \\
162 \cdot 5 \\
168 \cdot 0 \\
212 \cdot 0\end{array}$ \\
\hline \multirow[t]{3}{*}{ Total Australia } & 26,246 & $3 \cdot 9$ & 24,675 & $3 \cdot 7$ & 97 & $3 \cdot 7$ & 3,958 & $150 \cdot 8$ \\
\hline & & & & & \multicolumn{2}{|c|}{ Professional staff $\dagger$} & & \\
\hline & & & & & $\begin{array}{l}\text { Crude } \\
\text { total }\end{array}$ & $\begin{array}{c}\text { Per } 1,000 \\
\text { equipped } \\
\text { beds }\end{array}$ & & \\
\hline $\begin{array}{l}\text { 2. CANADA 1945 } \\
\text { Prince Edward Is. } \\
\text { Nova Scotia } \\
\text { New Brunswick } \\
\text { Quebec } \\
\text { Ontario } . . \\
\text { Manitoba } \\
\text { Saskatchewan } \\
\text { Alberta .. } \\
\text { British Columbia }\end{array}$ & $\begin{array}{r}290 \\
2,541 \\
1,000 \\
13,670 \\
16,572 \\
2,578 \\
2,970 \\
2,967 \\
2,536\end{array}$ & $\begin{array}{l}3 \cdot 2 \\
4 \cdot 1 \\
2 \cdot 1 \\
3 \cdot 8 \\
4 \cdot 1 \\
3 \cdot 5 \\
3 \cdot 5 \\
3 \cdot 6 \\
2 \cdot 7\end{array}$ & $\begin{array}{r}284 \\
2,241 \\
1,266 \\
14,219 \\
15,585 \\
3,075 \\
4,217 \\
3,057 \\
4,112\end{array}$ & $\begin{array}{l}3 \cdot 1 \\
3 \cdot 6 \\
2 \cdot 7 \\
4 \cdot 0 \\
3 \cdot 9 \\
4 \cdot 2 \\
5 \cdot 0 \\
3 \cdot 7 \\
4 \cdot 3\end{array}$ & $\begin{array}{r}3 \\
29 \\
8 \\
80 \\
137 \\
20 \\
22 \\
14 \\
30\end{array}$ & $\begin{array}{r}10 \cdot 3 \\
11 \cdot 4 \\
8 \cdot 0 \\
5 \cdot 9 \\
8 \cdot 3 \\
7 \cdot 8 \\
7 \cdot 4 \\
4 \cdot 7 \\
11 \cdot 8\end{array}$ & $\begin{array}{r}16 \\
96 \\
81 \\
832 \\
1,629 \\
222 \\
438 \\
207 \\
320\end{array}$ & $\begin{array}{r}55 \cdot 2 \\
37 \cdot 8 \\
81 \cdot 0 \\
60 \cdot 9 \\
98 \cdot 3 \\
86 \cdot 1 \\
147 \cdot 5 \\
69 \cdot 8 \\
126 \cdot 2\end{array}$ \\
\hline Total Canada & 45,124 & $3 \cdot 7$ & 48,056 & $3 \cdot 9$ & 343 & $7 \cdot 6$ & 3,841 & $85 \cdot 1$ \\
\hline
\end{tabular}

* The figures relate to years ended as follows: N.S.W., Queensland, Tasmania, June 30, 1944; others, December $31,1943$.

$\dagger$ Includes dentists and psychologists. 
the year, the second from the total patient days during which beds were occupied during the year divided by the total number of individuals who have been under care on that period. Clearly neither figure is what is really wanted, but in fact the two do not differ greatly and may be taken as a rough practical estimate of the true figure. These figures are shown in Table VII.

\section{TABLE VII}

Estimates of Mean Duration of Stay of Patients in Canadian Hospitals in 1945

\begin{tabular}{|c|c|c|c|c|}
\hline & \multirow{2}{*}{\multicolumn{2}{|c|}{$\begin{array}{c}\text { Ratio of } \\
\text { patients } \\
\text { in hospi- } \\
\text { tal at end } \\
\text { of year } \\
\text { to those } \\
\text { at begin- } \\
\text { ning }\end{array}$}} & \multicolumn{2}{|c|}{$\begin{array}{c}\text { Average stay in } \\
\text { days }\end{array}$} \\
\hline & & & $\begin{array}{c}\text { From } \\
\text { dis- } \\
\text { charges }\end{array}$ & $\begin{array}{c}\text { From } \\
\text { all } \\
\text { patients } \\
\text { under } \\
\text { care }\end{array}$ \\
\hline 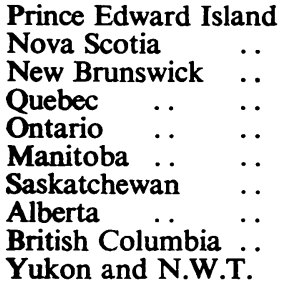 & \begin{tabular}{l|}
$\cdots$ \\
$\cdots$ \\
$\cdots$ \\
$\cdots$ \\
$\cdots$ \\
$\cdots$ \\
$\cdots$ \\
$\cdots$ \\
$\cdots$ \\
$\cdots$
\end{tabular} & $\begin{array}{l}101 \cdot 2 \\
101 \cdot 2 \\
126 \cdot 7 \\
106 \cdot 2 \\
113 \cdot 2 \\
100 \cdot 2 \\
115 \cdot 9 \\
114 \cdot 6 \\
101 \cdot 3 \\
104 \cdot 3\end{array}$ & $\begin{array}{r}7 \cdot 8 \\
10 \cdot 0 \\
11 \cdot 0 \\
14 \cdot 5 \\
10 \cdot 8 \\
10 \cdot 6 \\
9 \cdot 8 \\
9 \cdot 8 \\
11 \cdot 7 \\
19 \cdot 7\end{array}$ & $\begin{array}{r}7 \cdot 8 \\
10 \cdot 4 \\
10 \cdot 9 \\
15 \cdot 2 \\
11 \cdot 6 \\
10 \cdot 7 \\
10 \cdot 0 \\
9 \cdot 9 \\
11 \cdot 7 \\
30 \cdot 3\end{array}$ \\
\hline Total Canada & $\cdots$ & $109 \cdot 2$ & $11 \cdot 4$ & $11 \cdot 9$ \\
\hline
\end{tabular}

We can readily see from the Table that the differences in mean duration given by the discharge figures are due to some cause other than the inaccuracy inherent in the method of calculation. In default of far more detailed information concerning the nature, age, and sex of the cases treated it is not possible to assign these differences to any particular scheme of concomitant events.

\section{Assessment of the Administrative Problem}

The passing of British hospitals to the control of Regional Boards will necessarily involve dispersing the obscurity that, despite the Hospital Survey of 1945, still covers much of their activity. Properly conducted collection of statistics is a necessary part of the accountancy of large-scale administration. It is clear from examination of Dominions data that the problem of what statistics are to be collected to clarify administrative work still requires considerable thought and experiment. In the past such statistics have too often been regarded as a record of trusteeship - colonial governments still solemnly publish as "medical statistics" crude figures of how many samples of water have been tested in public laboratories. What is required is clear assessment of the administrative problems to be answered before collection of the data is entered upon. In this particular weight must be attached to the problem of preparing, in an economy of shortages, a rational system of accounting that will enable planning committees to establish a system of priorities based on the facts of community requirements, rather than the special pleading of interested experts. For planning purposes it is possible to suggest certain figures that will necessarily be required; others can come to be realized only as a result of experience.

\section{Suggestion for a Minimal Accountancy of BeD-STATES}

If we disregard staffing figures, where the problem is largely one of uniformity of definition and careful delineation of the contribution of part-time staff, the ensuing paragraphs suggest a minimal accountancy relating solely to the bed-states. Over a discreet interval of time a true balance of admissions and discharges will consist of the following:

$\begin{array}{cc}\begin{array}{c}\text { Persons in hospital at } \\ \text { beginning of period }\end{array} & \begin{array}{c}\text { Discharges from hospi- } \\ \text { tal }\end{array} \\ \text { New admissions } & \begin{array}{c}\text { Transfers to other hos- } \\ \text { pitals }\end{array} \\ \begin{array}{c}\text { In transfers from other } \\ \text { hospitals }\end{array} & \begin{array}{c}\text { Deaths in hospital } \\ \text { Persons in hospital at } \\ \text { end of period } \\ \text { Total B }\end{array} \\ \text { Total A } & \text { Total B }\end{array}$

The totals on each side of this schema must balance. Ideally such figures should be kept separately by sex and by some subdivision by age. For the United Kingdom it is probable that a fourfold age split, viz. 0-4 years, 5-15, 16-64, and over 64, would suffice for most administrative purposes; this follows the administrative subdivisions of life in the social-service state of pre-school, school, working life, and old age pensioners. A minor complication arises in respect of births in hospital; probably the ideal solution to this is provided by the Canadian practice of recording separately admissions of adults and children, and the newborn. In this case the newborn fit a schema such as the above, except that new admissions come only as a result of birth.

As a routine check on the degree to which beds are employed a quite simple measure can be made where the highest and lowest number of beds to be occupied on any one day during the accounting period is available for comparison with the number of equipped beds. In estimating requirements the above figures may be used in conjunction with information regarding waiting lists. Ideally, information should be obtained in such a way as to give 
the distribution of different lengths of time spent waiting admission; in default of this it would at least be desirable to know the movement of patients on waiting lists during the accounting period. This should be done again on some form of balancing schema such as that for admissions and discharges. Here the schema could take the following form:

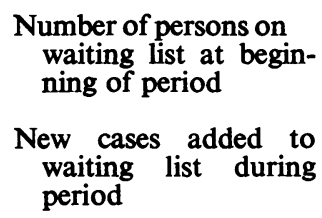

No. of cases struck off waiting list consequent on:

a. Admission to hospital

b. Removal to anc. Death other area

No. on waiting list at end of period

Again this schema should balance. The data are, however, more difficult of collection, and a complication may arise where one person appears simultaneously on the waiting lists of more than one institution. Neither difficulty would arise seriously, however, where waiting lists were administered centrally.

In addition to the above figures a breakdown by age and sex of the distribution of time spent in hospital should from time to time be provided.

In planning any scheme for the collection of such statistics international comparability comes low on the scale of requirements. Indeed it may not be easy at first to achieve comparability between institutions in the same region, for the local variations of practice that make accurate definition of terms difficult are not always trivial or absurd.

While it is desirable that clear information should be assembled for administrative use, the tail must not be allowed to wag the dog. Uniformity of treatment is attractive to the statistician, for it simplifies his taxonomic problems; but it does not always lead to humane administration.

This paper was written while in receipt of a grant from the Halley Stewart Trust, to whom my thanks are due.

Australia (1944-5). Official Year Book of the Commonwealth of Australia No. 36. Commonwealth Bureau of Census and Statistics, Canberra.

Canada (1945). Annual Report of Hospitals in Canada. Dominion Bureau of Statistics, Ottawa.

- (1945). Annual Report of Tuberculosis institutions for the year 1945. Dominion Bureau of Statistics, Ottawa.

(1946). The Canada Year Book 1946. Ottawa.

England and Wales (1945). Report of the Chief Medical Officer of Health on the State of Public Health for 1945.

New Zealand (1944). Department of Health. Appendix to the Annual Report for the year ended March 31, 1944.

Charles, E. (1945). "Cultural differences in Family Size." Canada, Dominion Bureau of Statistics Bulletin F.2. Ottawa.

Emerson, H. (1943). "Some lessons of the hospital survey for New York" in "The Hospital in Modern Society". Commonwealth Fund, New York. 